\title{
Parent Progeny Regression and Correlation Analysis in Segregating Population of Black Gram [Vigna mungo (L.) Hepper]
}

\author{
Rakesh Gandi* and N. Shunmughavalli
}

Agricultural College and Research Institute, Killikulam (TNAU), India

*Corresponding author

A B S T R A C T

\section{Keywords \\ Black gram, \\ Correlation and regression \\ Article Info \\ Accepted: \\ 10 March 2018 \\ Available Online: \\ 10 April 2018}

In the present investigation, nine crosses of black gram (Vigna mungo L.) were evaluated in $\mathrm{F}_{2}$ and $\mathrm{F}_{3}$ generations for the effective selection for yield and yield components. The segregating generation of the crosses included were PU 06-20 x VBN 4, IPU 2006-01 x ADT3, IPU 2006-01 x VBN 4, IPU 2006-01 x TNY LOCAL, IPU 02-33 x VBN 4, IPU 02-33 x VBN 4, IPU 02-33 x TNY LOCAL, WBG 26 x VBN 3, MASH 114 x VBN 3 and MASH 114 x TNY LOCAL. One way of ascertaining the influence of environment on different characters is parent-progeny regression. In the present study all characters exhibited non-significant both positive and negative direction. This indicated that there is no relationship between $\mathrm{F}_{2}$ values and its progeny mean.

\section{Introduction}

Black gram is also called as urd bean and black lentil. It is an important multipurpose grain legume extensively cultivated in arid, semi-arid and subtropics. Black gram is photo insensitive in nature and can be cultivated throughout the year. Black gram fits well in different cropping system as it is relatively drought tolerant. It is also grown as catch crop, mulch crop inter crop, mixed crop and green crop. Jayamani et al., (2012) reported that about 70 percent of the total pulse production area is in the central and southern parts of the country and this contributes about more than 77 per cent of the total production. To evolve new black gram varieties, recombination breeding has been recognized as successful method by plant breeders. This involves a systemic pedigree selection initiated in the $F_{2}$ which exhibits a wide range of variation. Selection made on $\mathrm{F}_{2}$ based on grain yield is in sufficient, since the single plant yield is the result of cumulative effect of both genotype and environment. Selection is effective only if the, performance of $\mathrm{F}_{3}$ lines is more dependable than that of $F_{2}$ performance. Hence it is necessary to evaluate that how far the $F_{2}$ values have bearing on $F_{3}$ mean and whether such parameter relied upon selection. Its real genetic potentiality can be ascertained by only the progeny performance of the individual selection, since the mean of progeny is more reliable estimate than, individual values of selected parents. One way of ascertaining the influence of environment 
on different characters is parent-progeny regression (Lush, 1940).

\section{Materials and Methods}

The material for the present study was generated at the Department of Plant Breeding and Genetics, Agricultural College and Research Institute (TNAU) Killikulam. Nine high yielding cross combinations were selected from the $F_{1}$ generation of the previous study based single plant yield along with the VBN 4 variety as the check. The experiment was laid out in homogenous block following randomized block design (RBD) with three replications. The spacing between the rows was $30 \mathrm{~cm}$ and spacing between the individual plants was $10 \mathrm{~cm}$. Recommended agronomic practices were followed to raise the crop. Observations on 8 quantitative characters were recorded. The correlation and regression coefficient values were estimated by using the statistical methods suggested by Lush (1940).

\section{Results and Discussion}

In the present study all characters exhibited non-significant both positive and negative direction (Table 1). This indicated that there is no relationship between $F_{2}$ values and its progeny mean. MC Ginnis and Shebeski (1968) also obtained non - significant correlation between $F_{2}$ and $F_{3}$ reported that on this basis alone, there was no advantage in selecting $\mathrm{F}_{2}$ plants for high yield. The absence of relationship between $F_{2}$ and $F_{3}$ indicates that the interference of non-additive components is very considerable, and hence the scheme of selection should be postponed to later generations.

The selected trait, single plant yield exhibits non-significant positive correlation observed in pods per cluster, number of pods per plant, number of seeds per pod and 100 seed weight such positive correlation and regression between $F_{2}$ and $F_{3}$ indicates that it is possible to exercise selection effectively in a wide population (Singh and Alie, 2009). The trait plant height exhibited non-significant positive values for all the crosses where as WBG $26 \mathrm{x}$ VBN 3 showed non- significant negative values for single plant yield, seeds per pod, pods per plant and pod length. The unselected characters or traits non-significant and positive correlation values were recorded for plant height and clusters per plant in all the crosses. The trait plant height exhibited nonsignificant positive values for all the crosses where as WBG $26 \times$ VBN 3 showed nonsignificant negative values for single plant yield, seeds per pod, pods per plant and pod length (Table 1).

IPU 2006- $01 \mathrm{x}$ VBN 4 and IPU 2006-01 $\mathrm{x}$ TNY LOCAL showed non-significant negative values for the trait seeds per pod and pods per cluster (Table 1). The reason for such negative inter relationship was that the genotypes which were heterozygous and heterogeneous in $F_{2}$ fails to transfer their genetic potentiality completely (Ramesh, 1990). This might be also due to the higher accumulation of heterozygous genes in $F_{2}$, which is generated further in $F_{3}$. In these crosses phenotypic selection of segregants should not be restored to in $F_{2}$ generation or otherwise, selection is to postponed to succeeding generations. Instead selection based on yield components done and not by yield directly (Manuel et al., 1997). There are several reasons by Meredith and Bridge (1973) to explain why the $F_{2}$ performance may not closely related to that of $\mathrm{F}_{3}$ progeny mean. The environment of an individual plant differs greatly from the progeny rows. The second factor is that the genotype $\mathrm{x}$ environment interactions from one year to the next at a single selection may be large. Dominance gene action in an $F_{2}$ population may not be useful in the later generations i.e., large non additive gene effects. 
Table.1 Parent progeny regression and correlation

\begin{tabular}{|c|c|c|c|c|c|c|c|c|c|c|}
\hline Characters & & $\begin{array}{c}\text { PU 06-20 x } \\
\text { VBN } 4\end{array}$ & $\begin{array}{c}\text { IPU 2006- } \\
01 \text { x ADT } 3\end{array}$ & $\begin{array}{l}\text { IPU 2006- } \\
01 \text { x VBN } 4\end{array}$ & $\begin{array}{c}\text { IPU 2006- } \\
01 \text { x TNY } \\
\text { LOCAL }\end{array}$ & $\begin{array}{c}\text { IPU 02-33 } \\
x \text { VBN } 4\end{array}$ & $\begin{array}{c}\text { IPU 02-33 } \\
\text { x TNY } \\
\text { LOCAL }\end{array}$ & $\begin{array}{l}\text { WBG } 26 \\
x \text { VBN } 3\end{array}$ & $\begin{array}{l}\text { MASH } \\
114 x \text { VBN } 3\end{array}$ & $\begin{array}{c}\text { MASH } \\
114 x \\
\text { TNY } \\
\text { LOCAL }\end{array}$ \\
\hline \multirow[t]{2}{*}{ PH } & $\mathbf{r}$ & 0.103 & 0.313 & 0.809 & 0.464 & 0.554 & 0.709 & 0.752 & 0.886 & 0.463 \\
\hline & b & 0.040 & 0.405 & 0.955 & 0.647 & 0.727 & 0.939 & 0.802 & 0.968 & 0.444 \\
\hline \multirow[t]{2}{*}{ CPP } & $\mathbf{r}$ & 0.457 & 0.776 & 0.905 & 0.467 & 0.547 & 0.494 & 0.226 & 0.422 & 0.575 \\
\hline & $\mathbf{b}$ & 0.121 & 0.378 & 0.519 & 0.214 & 0.341 & 0.580 & 0.054 & 0.615 & 0.209 \\
\hline \multirow[t]{2}{*}{ PPC } & $\mathbf{r}$ & 0.515 & 0.446 & -0.172 & -0.443 & -0.372 & 0.417 & 0.407 & 0.602 & -0.358 \\
\hline & b & 0.898 & 0.987 & -0.971 & -0.860 & -0.859 & 0.806 & 0.853 & 0.869 & -0.952 \\
\hline \multirow[t]{2}{*}{ PL } & $\mathbf{r}$ & 0.509 & 0.920 & 0.509 & 0.916 & 0.114 & -0.148 & -0.047 & 0.209 & 0.885 \\
\hline & b & 0.904 & 0.843 & 0.825 & 0.846 & 0.857 & -0.756 & -0.839 & 0.956 & 0.786 \\
\hline \multirow[t]{2}{*}{ PPP } & $\mathbf{r}$ & 0.467 & -0.059 & 0.504 & 0.961 & 0.935 & 0.096 & -0.345 & -0.102 & 0.995 \\
\hline & b & 0.862 & -0.869 & 0.408 & 0.789 & 0.836 & 0.925 & -0.965 & -0.856 & 0.800 \\
\hline \multirow[t]{2}{*}{ SPP } & $\mathbf{r}$ & 0.112 & 0.508 & -0.121 & -0.574 & 0.308 & 0.511 & -0.345 & -0.325 & -0.528 \\
\hline & b & 0.107 & 0.336 & -0.865 & -0.995 & 0.300 & 0.752 & -0.774 & -0.921 & -0.886 \\
\hline \multirow[t]{2}{*}{ HSW } & $\mathbf{r}$ & 0.553 & 0.409 & 0.256 & 0.256 & -0.207 & 0.299 & 0.156 & 0.259 & 0.289 \\
\hline & b & 0.956 & 0.968 & 0.785 & 0.859 & -0.864 & 0.789 & 0.964 & 0.635 & 0.864 \\
\hline \multirow[t]{2}{*}{ SPY } & $\mathbf{r}$ & -0.084 & 0.703 & 0.955 & 0.659 & -0.546 & 0.685 & -0.089 & 0.702 & 0.802 \\
\hline & b & -0.089 & 0.435 & 0.352 & 0.985 & -0.869 & 0.796 & -0.974 & 0.578 & 0.616 \\
\hline
\end{tabular}




\section{References}

Jayamani, P., N. Kumaravadivel, N. Nadarajan, A.R. Muthiah, C. Durairaj, A. Kamalakannan, S. Pazhanivelan and K. Thiyagarajan. 2012. TNAU Black gram CO6: A High Yielding Short Duration Variety. Madras Agric. J., 99(1-3):34-36.

Lush, L.1940.Intra-sire correlations or regressions of offspring on dam as a method of estimating heritability of characteristics. AnnProc ASAP., 33: 293-301.

Manuel, W.W., B. Prem Kumar and S. Sevugaperumal. 1997. Limitations of selections for Yield in $F_{2}$, Aduthurai Reporter, 1: 128-129.

Meredith, W.R., J.R. and R.R. Bridge.1973.The relationship between $\mathrm{F}_{2}$ and $\mathrm{F}_{3}$ progenies in cotton $(G$. hirsutum L.). Crop Sci., 9: 752-775.

Ramesh, M.1990. Genetic variability studies in $\mathrm{F}_{2}$ and $\mathrm{F}_{3}$ of rice (Oryza sativa L.). M.Sc (Ag).Thesis, Tamil Nadu Agric. Univ., Coimbatore.

Singh, T., A. Sharma and F.A. Alie. 2009. Impact of environment on heritability and genetic gain for yield and its component traits in mungbean. Legume Res., 32(1): 55-58.

\section{How to cite this article:}

Rakesh Gandi and Shunmughavalli, N. 2018. Parent Progeny Regression and Correlation Analysis in Segregating Population of Black Gram [Vigna mungo (L.) Hepper]. Int.J.Curr.Microbiol.App.Sci. 7(04): 986-989. doi: https://doi.org/10.20546/ijcmas.2018.704.106 